\title{
ANALISIS PENGARUH KUALITAS INFORMASI \\ DAN PEMAHAMAN AKUNTANSI TERHADAP \\ KUALITAS LAPORAN KEUANGAN PADA \\ USAHA KECIL DAN MENENGAH (UKM) DI KABUPATEN TANGERANG
}

\section{Lena Erdawati}

Universitas Muhammadiyah Tangerang

\begin{tabular}{l}
\hline INF O A R TKE L \\
Keyword: \\
Quality of information, \\
Understanding of accounting, \\
Quality of financial statements
\end{tabular}

Corresponding author: lena.erdawati@yahoo.co.id

\section{A B S T R A C T}

The purpose of the study is to analyze how much influence the quality of information and the understanding of accounting on the quality of financial statements on small and medium business (SMEs) in Tangerang Regency. Respondents include owners/managers of SMEs as many as 54 people. The sampling technique uses sensus sampling. Data collection using questionnaire. The method used in this research is the method of verification to determine the effect of quality of information and understanding of accounting on the quality of financial statements. The test statistic used is designing the structural model, designing a measurement model, construct the path diagram, test the model fit. Suitability test structural models and hypotheses using software SmartPLS 3.0. The results showed that the quality of information and the understanding of accounting have a significant effect on the quality of financial statements.

\section{INTI SAR I}

Tujuan penelitian ini untuk menganalisis seberapa besar pengaruh kualitas informasi dan pemahaman akuntansi terhadap kualitas laporan keuangan pada usaha kecil dan menengah (UKM) di Kabupaten Tangerang. Responden sebanyak 54 orang setingkat pemilik / pengelola UKM. Teknik pengambilan sampel menggunakan sensus. Pengumpulan data menggunakan kuesioner. Metode yang digunakan dalam penelitian ini adalah metode verifikasi untuk mengetahui pengaruh kualitas informasi dan pemahaman akuntansi terhadap kualitas laporan keuangan. Statistik uji yang digunakan adalah model struktural, model pengukuran, diagram alur, kesesuaian model. Uji kesesuaian model struktural dan hipotesis menggunakan perangkat lunak SmartPLS 3.0. Hasil penelitian menunjukkan bahwa kualitas informasi dan pemahaman akuntansi memiliki pengaruh yang signifikan terhadap kualitas laporan keuangan. 


\section{PENDAHULUAN}

\section{Latar Belakang Masalah}

UKM berperan menjadi tulang punggung bagi ekonomi Indonesia. Hal ini dikarenakan sebagian besar jumlah penduduknya hidup dalam kegiatan usaha kecil baik di sektor tradisional maupun modern.

Pencatatan akuntansi yang baik akan menghasilkan laporan keuangan yang berkualitas dan sesuai dengan standar akuntansi untuk UKM yaitu SAK ETAP. Laporan keuangan yang berkualitas akan sangat membantu UKM dalam memperoleh modal usaha bank.

Dengan akuntansi yang memadai maka pengusaha dapat memenuhi persyaratan dalam pengajuan kredit berupa laporan keuangan, mengevaluasi kinerja, mengetahui posisi keuangan, menghitung pajak, dan manfaat lainnya (Warsono, 2010).

Kabupaten Tangerang dipilih untuk menjadi objek penelitian karena pesatnya tumbuh kembang UKM di kabupaten tersebut diharapkan diimbangi pula dengan peningkatan kualitas UKM itu sendiri terutama dalam hal penggunaan informasi akuntansi untuk kelangsungan dan keberhasilan usaha di waktu yang akan datang.

\section{Rumusan Masalah} adalah:

Rumusan masalah dalam penelitian ini

I. Apakah kualitas informasi berpengaruh signifikan terhadap kualitas laporan keuangan pada usaha kecil dan menengah (UKM) di Kabupaten Tangerang?

2. Apakah pemahaman akuntansi berpengaruh signifikan terhadap kualitas laporan keuangan pada usaha kecil dan menengah (UKM) di Kabupaten Tangerang?

\section{Tujuan Penelitian}

Adapun tujuan penelitian ini adalah untuk menganalisis pengaruh:

I. Kualitas informasi terhadap kualitas laporan keuangan pada usaha kecil dan menengah (UKM) di Kabupaten Tangerang?

2. Pemahaman akuntansi terhadap kualitas laporan keuangan pada usaha kecil dan menengah (UKM) di Kabupaten Tangerang?

\section{Kegunaan Penelitian}

\section{Kegunaan Praktis}

Hasil Penelitian ini diharapkan dapat menjadi bahan pertimbangan untuk pemecahan masalah-masalah bagi UKM dalam mengatasi kualitas laporan keuangan yang belum baik. Berdasarkan latar belakang masalah, kualitas laporan keuangan dapat diperbaiki dengan kualitas informasi dan pemahaman akuntansi.

\section{Kegunaan Akademis}

Hasil penelitian diharapkan dapat memberi mamfaat dan selain itu mengembangkan ilmu, dimana teori yang telah ada diuji kembali dalam penelitian ini dapat memperkuat teori yang telah ada yaitu kualitas informasi dan pemahaman akuntansi terhadap kualitas laporan keuangan.

\section{TINJAUAN PUSTAKA}

\section{Kualitas Laporan Keuangan}

Agar dapat menyediakan informasi yang berguna dan bermanfaat bagi pihak-pihak yang berkepentingan, maka informasi yang disajikan dalam pelaporan keuangan harus memenuhi karakteristik kualitatif sehingga dapat digunakan dalam pengambilan keputusan (Obaidat, 2007; Hapsari, 2007).

Indikator variabel kualitas laporan keuangan diukur dari relevan, andal, dapat dibandingkan dan dapat dipahami.

\section{Kualitas Informasi}

Menurut Gelinas et al (2010), informasi akuntansi yang berkualitas adalah informasi yang memberikan manfaat bagi para pengambil keputusan. James A Hall (2007) menyampaikan bahwa informasi yang berkualitas tinggi adalah informasi yang dapat membantu pengguna untuk melakukan tindakan yang di harapkan.

Indikator variabel kualitas informasi diukur dari pelatihan akuntansi, teknologi informasi, integritas dan kontinyuitas.

\section{Pemahaman Akuntansi}

Menurut Yuliani (2010) untuk dapat menghasilkan laporan keuangan yang berkualitas maka kualitas orang-orang yang melaksanakan tugas dalam menyusun laporan keuangan harus menjadi perhatian utama yaitu para pegawai yang terlibat dalam aktivitas tersebut harus mengerti dan memahami bagaimana proses dan pelaksanaan akuntansi itu dijalankan dengan berpedoman pada ketentuan yang berlaku. 
Indikator variabel pemahaman akuntansi diukur dari pengetahuan akuntansi, pengalaman dalam informasi akuntansi dan pengetahuan pinjaman modal.

\section{Kerangka Pemikiran Teoritis}

Ada hal yang perlu diperhatikan agar dapat menyusun laporan keuangan yang berkualitas. Maka perlu adanya kaualitas informasi yang baik, sehingga penyusunan dan penyajian laporan keuangan usaha kecil dan menengah (UKM) dapat sesuai dengan kualitas yang diharapkan.

Kualitas informasi yang baik dapat meningkatkan kualitas laporan keuangan usaha kecil dan menengah (UKM). Jika kualitas informasi baik, maka dapat menghasilkan laporan keuangan dengan kualitas yang baik pula.

Laporan keuangan merupakan sebuah produk yang dihasilkan oleh bidang atau disiplin ilmu akuntansi. Oleh karena itu, dibutuhkan sumber daya manusia yang kompeten untuk menghasilkan sebuah laporan keuangan yang berkualitas.

Untuk dapat menghasilkan laporan keuangan yang berkualitas maka kualitas orangorang yang melaksanakan tugas dalam menyusun laporan keuangan harus menjadi perhatian utama yaitu para karyawan yang terlibat dalam aktivitas tersebut harus mengerti dan memahami bagaimana proses dan pelaksanaan akuntansi itu dijalankan dengan berpedoman pada ketentuan yang berlaku.

Jadi dapat disimpulkan bahwa semakin baik pemahaman akuntansi maka semakin baik kualitas laporan keuangan usaha kecil dan menengah (UKM).

Berdasarkan kerangka pemikiran di atas maka peneliti merumuskan kerangka konseptual sebagai berikut:

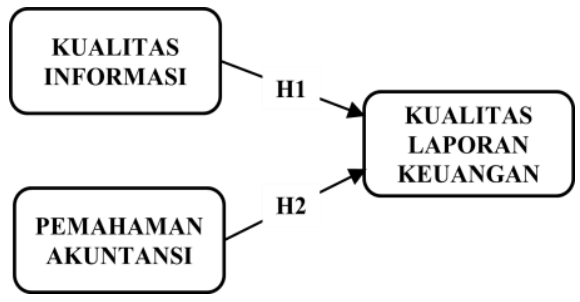

Gambar 2.I Kerangka Konseptual

Berdasarkan kerangka konseptual pada Gambar 2.I, maka dapat dirumuskan hipotesis sebagai berikut:
$\mathrm{HI}$ : Kualitas informasi berpengaruh terhadap kualitas laporan keuangan pada usaha kecil dan menengah (UKM) di Kabupaten Tangerang.

$\mathrm{H} 2$ : Pemahaman akuntansi berpengaruh terhadap kualitas laporan keuangan pada usaha kecil dan menengah (UKM) di Kabupaten Tangerang.

\section{METODOLOGI PENELITIAN}

\section{Metode Penelitian}

Metode yang digunakan dalam penelitian ini adalah metode penelitian verifikatif. Menurut Mashuri (2008) metode penelitian verifikatif adalah metode yang digunakan untuk memeriksa benar tidaknya apabila dijelaskan untuk menguji suatu cara dengan atau tanpa perbaikan yang telah dilaksanakan di tempat lain dengan mengatasi masalah yang serupa dengan kehidupan.

\section{Populasi, Sampel dan Teknik Pengambilan Sampel}

Populasi dalam penelitian ini adalah seluruh UKM di Kabupaten Tangerang. Sampel dalam penelitian ini terdiri atas sejumlah anggota yang dipilih dari populasi (Sekaran dan Bougie, 2009). Sampel yang digunakan dalam penelitian ini adalah pemilik atau pengelola di masingmasing UKM.

Teknik Pengambilan Sampel dalam penelitian ini menggunakan metode sampel jenuh yaitu Sampel jenuh adalah teknik sampling bila semua anggota populasi digunakan sebagai sampel (Sugiyono, 2012). Dari 54 UKM yang ada di Kabupaten Tangerang, peneliti mengambil sampel 54 pemilik atau pengelola untuk masingmasing UKM.

\section{Metode Pengumpulan Data}

Metode pengumpulan data yang digunakan dalam penelitian ini adalah metode kuisioner. Kuisioner adalah sejumlah pertanyaan tertulis yang digunakan untuk memperoleh informasi dari responden dalam arti laporan tentang halhal yang ia ketahui (Arikunto, 2006).

Survei mengumpulkan data primer diperoleh dengan cara membagikan sejumlah kuesioner kepada para responden dan kemudian responden akan mengisinya sesuai dengan pendapat dan persepsi responden. 
Kuesioner dalam penelitian ini disusun menggunakan skala Likert. Penelitian ini akan menggunakan skala Likert I-5 dengan rincian sebagai berikut:

$$
\begin{aligned}
& 1=\text { sangat tidak setuju } \\
& 2=\text { tidak setuju } \\
& 3=\text { netral } \\
& 4=\text { tidak setuju } \\
& 5=\text { sangat setuju }
\end{aligned}
$$

\section{Operasional Variabel}

Operasionalisasi variabel menurut Supomo dan Indriantoro (2002) adalah penentuan konstruk sehingga menjadi variabel yang dapat diukur.

Operasionalisasi variabel diperlukan untuk menentukan jenis, indikator, serta skala dari variabel-variabel yang terkait dalam penelitian, sehingga pengujian hipotesis dengan alat bantu statistik dapat dilakukan secara benar sesuai dengan judul penelitian. Variabel-variabel yang akan diukur dalam penelitian ini yaitu:

I. Variabel bebas atau independen

Menurut Sugiyono (20/3), variabel bebas adalah variabel yang akan mempengaruhi atau yang menjadi sebab perubahannya atau timbulnya variabel dependen (terikat). Variabel independen pada penelitian ini adalah kualitas informasi dan organisasi, sumber daya manusia, pemahaman akuntansi dan modal, sistem pengendalian internal, aspek manajerial

2. Variabel terikat atau dependen

Menurut Sugiyono (2013), variabel terikat adalah variabel yang dipengaruhi atau yang menjadi akibat karena adanya variabel bebas. Variabel dependen dalam hal ini adalah kualitas laporan keuangan.

Variabel dan indikator yang digunakan dalam penelitian ini dijelaskan dalam tabel 3.I berikut ini:

Tabel 3.I Variabel dan Indikator Penelitian

\begin{tabular}{|l|l|}
\hline \multicolumn{1}{|c|}{ Variabel } & \multicolumn{1}{|c|}{ Indikator } \\
\hline \multirow{2}{*}{$\begin{array}{l}\text { Kualitas } \\
\text { Informasi } \\
\left(\xi_{1}\right)\end{array}$} & Pelatihan Akuntansi $\left(\mathrm{X}_{1}\right)$ \\
\cline { 2 - 2 } & Teknologi Informasi $\left(\mathrm{X}_{2}\right)$ \\
\cline { 2 - 2 } & Integritas $\left(\mathrm{X}_{3}\right)$ \\
\cline { 2 - 2 } $\begin{array}{l}\text { Pemahaman } \\
\text { Akuntansi } \\
\left(\xi_{2}\right)\end{array}$ & Kontinyuitas $\left(\mathrm{X}_{4}\right)$ \\
\cline { 2 - 2 } & Pengetahuan akuntansi $\left(\mathrm{X}_{5}\right)$ \\
\hline Kualitas & Akuntansi $\left(\mathrm{X}_{6}\right)$ \\
\cline { 2 - 2 } Laporan & Pengetahuan Pinjaman Modal $\left(\mathrm{X}_{7}\right)$ \\
\cline { 2 - 2 } & Relevan $\left(\mathrm{Y}_{1}\right)$ \\
\hline
\end{tabular}

\begin{tabular}{|l|l|}
\hline $\begin{array}{l}\text { Keuangan } \\
\left(n_{1}\right)\end{array}$ & Dapat dibandingkan $\left(\mathrm{Y}_{3}\right)$ \\
\cline { 2 - 2 } & Dapat dipahami $\left(\mathrm{Y}_{4}\right)$ \\
\hline
\end{tabular}

Sumber: dikembangkan untuk penelitian ini, 2017

\section{Metode Analisis}

Dalam penelitian ini peneliti menggunakan Partial Least Square (PLS) sebagai salah satu metode alternatif Structural Equation Modeling (SEM).

PLS digunakan dalam penelitian untuk mengukur hubungan setiap indikator dengan konstruknya. Selain itu, dalam PLS dapat dilakukan uji bootstrapping terhadap struktural model yang bersifat outer model dan inner model.

Langkah-langkah analisis dengan metode Partial Least Square (PLS) sebagai berikut:

I. Merancang Model Pengukuran (Outer Model)

Perancangan model ini digunakan untuk mengetahui validitas dan reliabilitas yang menghubungkan indikator dengan variabel latennya. Indikator dalam penelitian ini adalah reflektif karena indikator variabel laten mempengaruhi indikatornya.

2. Merancang Model Struktural (Inner Model)

Perancangan model struktural hubungan antar variabel laten didasarkan pada rumusan masalah atau hipotesis penelitian.

3. Konstruksi Diagram Jalur Penelitian

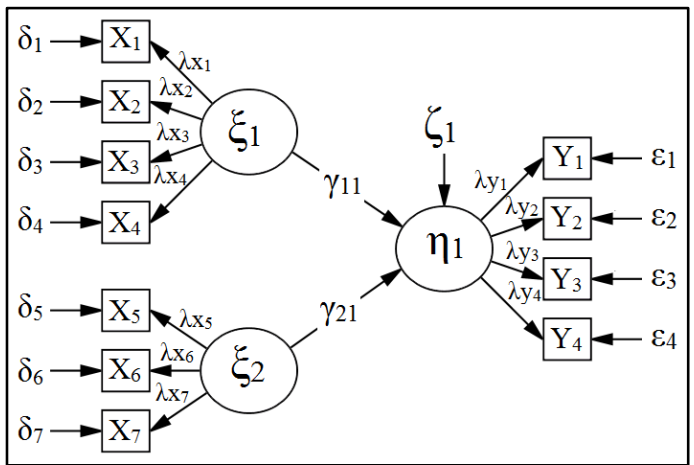

Gambar 3.I Konstruksi Diagram Jalur Penelitian

4. Konversi Diagram Jalur ke Sistem Persamaan

I) Inner Model

Inner model menentukan spesifikasi hubungan antara konstruk laten satu dengan kontrak laten lainnya.

Persamaan Inner Model:

$\eta_{1}=\gamma_{11} \xi_{1}+\gamma_{21} \xi_{2}+\zeta_{1}$

Keterangan:

$\xi_{1}=$ Konstruk laten eksogen kualitas informasi. 


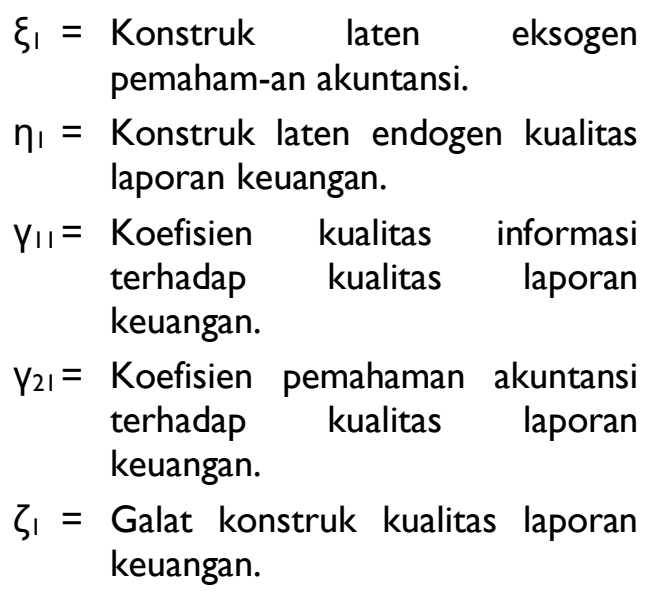

2) Outer Model

Outer Model menentukan spesifikasi hubungan antara konstruk laten dan indikatornya.

Persamaan Outer Model:

$\mathrm{X}_{1}=\lambda \mathrm{x}_{1} \xi_{1}+\delta_{1}$

$x_{2}=\lambda x_{2} \xi_{1}+\delta_{2}$

$x_{3}=\lambda x_{3} \xi_{1}+\delta_{3}$

$x_{4}=\lambda x_{4} \xi_{1}+\delta_{4}$

$x_{5}=\lambda x_{5} \xi_{2}+\delta_{5}$

$x_{6}=\lambda x_{6} \xi_{2}+\delta_{6}$

$\mathrm{X}_{7}=\lambda \mathrm{x}_{7} \xi_{2}+\delta_{7}$

$Y_{1}=\lambda y_{1} \eta_{1}+\varepsilon_{1}$

$Y_{2}=\lambda y_{2} \eta_{1}+\varepsilon_{2}$

$Y_{3}=\lambda y_{3} \eta_{1}+\varepsilon_{3}$

$Y_{4}=\lambda y_{4} \eta_{2}+\varepsilon_{4}$

Keterangan:

$$
\begin{aligned}
\lambda x_{1}-\lambda x_{4}= & \text { Koefisien indikator } \\
& \text { kualitas informasi. } \\
\lambda x_{5}-\lambda x_{7}= & \begin{array}{l}
\text { Koefisien indikator pema- } \\
\text { haman akuntansi. }
\end{array} \\
\lambda y_{1}-\lambda y_{4}= & \begin{array}{l}
\text { Koefisien indikator } \\
\text { kualitas laporan keuangan. }
\end{array} \\
\delta_{1}-\delta_{4}= & \begin{array}{l}
\text { Galat indikator kualitas } \\
\text { informasi. }
\end{array} \\
\delta_{5}-\delta_{7}= & \begin{array}{l}
\text { Galat indikator } \\
\text { pemahaman akuntansi. }
\end{array} \\
\varepsilon_{1}-\varepsilon_{4}= & \begin{array}{l}
\text { Galat indikator kualitas } \\
\text { laporan keuangan. }
\end{array}
\end{aligned}
$$

\section{Evaluasi Goodness of Fit}

Untuk memvalidasi model secara keseluruhan, maka digunakan goodness of fit (GoF). GoF index ini merupakan ukuran tunggal yang digunakan untuk memvalidasi performa gabungan antara model pengukuran (outer model) dan model structural (inner model). Nilai GoF index ini diperoleh dari averages communalities index (AVE) dikalikan dengan $R^{2}$ model.

$$
G o F=\sqrt{\overline{C o m \times R^{2}}}
$$

Nilai GoF ini terbentang antara 0 - I dengan interpretasi nilai adalah 0,1 (GoF kecil), 0,25 (GoF moderat), dan 0,38 (GoF besar).

\section{Uji Hipotesis (Resampling Bootstraping)}

Berdasarkan tujuan-tujuan penelitian, maka rancangan uji hipotesis yang dapat dibuat merupakan rancangan uji hipotesis dalam penelitian ini disajikan berdasarkan tujuan penelitian. Tingkat kepercayaan yang digunakan adalah $95 \%$, sehingga tingkat presisi atau batas ketidakakuratan sebesar $(\alpha)=5 \%=0,05$. Dan menghasilkan nilai $t$ tabel sebesar I,96.

Sehingga:

- Jika nilai t-hitung lebih kecil dari nilai ttabel (t-hitung < I.96), maka $\mathrm{H}_{0}$ diterima dan $\mathrm{H}_{\mathrm{a}}$ ditolak.

- Jika nilai t-hitung lebih besar dari nilai ttabel (t-hitung > I.96), maka $\mathrm{H}_{0}$ ditolak dan $\mathrm{H}_{\mathrm{a}}$ diterima.

\section{HASIL PENELITIAN}

\section{Evaluasi Model Pengukuran (Outer Model)}

Evaluasi ini meliputi dua tahap, yaitu evaluasi terhadap convergent validity dan discriminant validity.

\section{Evaluasi Convergent Validity}

Indikator validitas dapat dilihat dari nilai loading factor dan nilai t-hitung. Bila nilai loading factor suatu indikator lebih besar dari 0,50 dan nilai t-hitung lebih besar dari I,96; maka indikator tersebut dapat dikatakan valid. Sedangkan bila nilai loading factor lebih kecil dari 0,50 dan dan nilai t-hitung lebi kecil dari I,96; maka indikator tersebut dikeluarkan dari model.

Berikut adalah evaluasi model pengukuran terhadap indikator kualitas informasi, pemahaman akuntansi dan kualitas laporan keuangan dengan menggunakan perangkat lunak SmartPLS 3.0. 


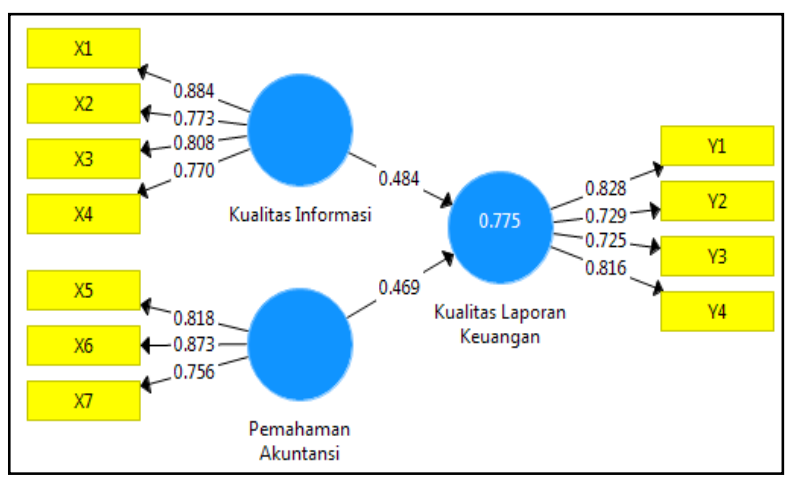

Gambar 4.I PLS Algorithm Output

Sumber: SmartPLS 3.0

Tabel 4. I Nilai Loading Factor Indikator

\begin{tabular}{|c|c|}
\hline Indikator & $\begin{array}{l}\text { Loading } \\
\text { Factor }\end{array}$ \\
\hline $\mathrm{XI} \leftarrow$ Kualitas Informasi & 0,884 \\
\hline $\mathrm{X} 2 \leftarrow$ Kualitas Informasi & 0,773 \\
\hline X3\& Kualitas Informasi & 0,808 \\
\hline X4\& Kualitas Informasi & 0,770 \\
\hline X5 $\leftarrow$ Pemahaman Akuntansi & 0,818 \\
\hline X6 $\leftarrow$ Pemahaman Akuntansi & 0,873 \\
\hline X7く Pemahaman Akuntansi & 0,756 \\
\hline YI $\leftarrow$ Kualitas Laporan Keuangan & 0,828 \\
\hline Y2 $\leftarrow$ Kualitas Laporan Keuangan & 0,729 \\
\hline Y3 $\leftarrow$ Kualitas Laporan Keuangan & 0,725 \\
\hline Y4ட Kualitas Laporan Keuangan & 0,816 \\
\hline
\end{tabular}

Sumber: Data primer diolah, 2017

Berdasarkan Gambar 4.I dan Tabel 4.I, semua indikator memiliki nilai loading factor lebih besar dari 0,70; maka semua indikator dapat dinyatakan valid.

Berikut evaluasi validitas berdasarkan nilai t-hitung sebagai uji signifikansi indikator.

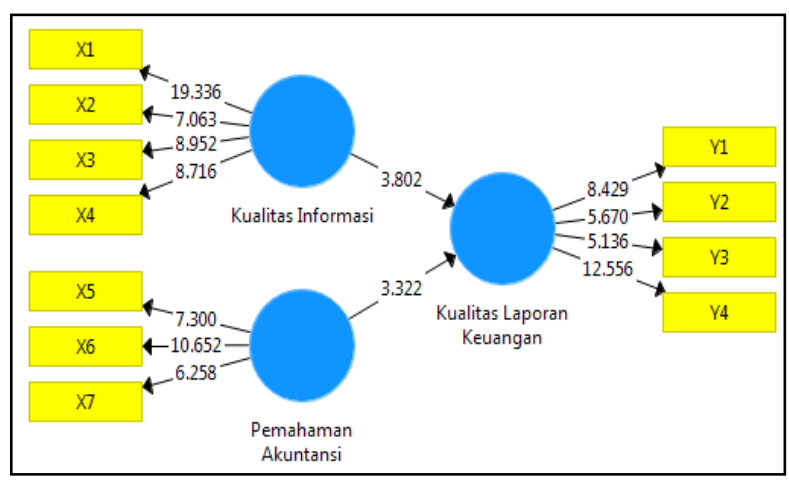

Gambar 4.2 PLS Bootstrapping Output

Sumber: SmartPLS 3.0

Tabel 4.I Nilai t-Hitung Indikator

\begin{tabular}{|l|r|}
\hline \multicolumn{1}{|c|}{ Indikator } & t-hitung \\
\hline X1 <-- Kualitas Informasi & 6,878 \\
\hline X2 - Kualitas Informasi & 6,568 \\
\hline X3 < - Kualitas Informasi & 7,601 \\
\hline X4 - Kualitas Informasi & 5,567 \\
\hline X5 - - Pemahaman Akuntansi & 6,206 \\
\hline X6 - Pemahaman Akuntansi & 9,623 \\
\hline X7 < - Pemahaman Akuntansi & 5,525 \\
\hline
\end{tabular}

\begin{tabular}{|l|r|}
\hline YI < - Kualitas Laporan Keuangan & 7,592 \\
\hline Y2 $<-$ Kualitas Laporan Keuangan & 5,203 \\
\hline Y3 < - Kualitas Laporan Keuangan & 4,778 \\
\hline Y4 < - Kualitas Laporan Keuangan & 7,042 \\
\hline \multicolumn{2}{|c|}{ Sumber: Data primer diolah (2017) }
\end{tabular}

Berdasarkan Gambar 4.2 dan Tabel 4.2, semua indikator memiliki nilai t-hitung lebih besar dari 1,96; maka semua indikator memiliki validitas yang signifikan.

Evaluasi selanjutnya dari convergent validity adalah reliabilitas konstruk dengan melihat nilai composite reliability dan nilai cronbach's alpha. Bila nilai composite reliability lebih besar dari 0,70 dan nilai cronbach's alpha lebih besar dari 0,50 maka konstruk dinyatakan reliabel.

Tabel 4.3

Nilai Composite Reliability dan Cronbach's Alpha

\begin{tabular}{|l|c|c|}
\hline \multicolumn{1}{|c|}{ Konstruk } & $\begin{array}{c}\text { Composite } \\
\text { Reliability }\end{array}$ & $\begin{array}{c}\text { Cronbach's } \\
\text { Alpha }\end{array}$ \\
\hline Kualitas Informasi & 0,884 & 0,828 \\
\hline $\begin{array}{l}\text { Pemahaman } \\
\text { Akuntansi }\end{array}$ & 0,858 & 0,781 \\
\hline $\begin{array}{l}\text { Kualitas Laporan } \\
\text { Keuangan }\end{array}$ & 0,857 & 0,750 \\
\hline
\end{tabular}

Sumber: Data primer diolah, 2017

Berdasarkan Tabel 4.3, semua konstruk memiliki nilai composite reliability lebih besar dari 0,70 dan nilai cronbach's alpha lebih besar dari 0,50; maka dapat disimpulkan semua konstruk reliabel.

Evaluasi terakhir dari convergent validity adalah melihat nilai average variance extracted (AVE).

Tabel 4.4 Nilai Average Variance Extracted (AVE)

\begin{tabular}{|l|c|}
\hline \multicolumn{1}{|c|}{ Konstruk } & AVE \\
\hline Kualitas Informasi & 0,656 \\
\hline Pemahaman Akuntansi & 0,602 \\
\hline Kualitas Laporan Keuangan & 0,667 \\
\hline
\end{tabular}

Sumber: Data primer diolah, 2017

Berdasarkan Tabel 4.4, semua nilai AVE konstruk lebih besar dari 0,50; maka dapat disimpulkan semua konstruk memiliki convergent validity yang baik.

\section{Evaluasi Discriminant Validity}

Evaluasi discriminant validity dilakukan dalam dua tahap, yaitu melihat nilai cross loadings dan membandingkan antara nilai kuadrat korelasi antara konstruk dengan nilai AVE atau korelasi konstruk dengan akar AVE. Kriteria dalam cross loadings adalah bahwa setiap 
indikator yang mengukur konstruknya haruslah berkorelasi lebih tinggi dengan konstruknya dibandingkan dengan konstruk lainnya. Hasil output cross loadings adalah sebagai berikut.

Tabel 4.5 Nilai Cross Loadings

\begin{tabular}{|c|c|c|c|}
\hline Indikator & $\begin{array}{c}\text { Kualitas } \\
\text { Informasi }\end{array}$ & $\begin{array}{c}\text { Pemahaman } \\
\text { Akuntansi }\end{array}$ & $\begin{array}{c}\text { Kualitas } \\
\text { Laporan } \\
\text { Keuangan }\end{array}$ \\
\hline $\mathrm{XI}$ & 0,884 & 0,816 & 0,676 \\
\hline $\mathrm{X} 2$ & 0,773 & 0,468 & 0,455 \\
\hline $\mathrm{X} 3$ & 0,808 & 0,727 & 0,672 \\
\hline $\mathrm{X} 4$ & 0,770 & 0,534 & 0,417 \\
\hline $\mathrm{X} 5$ & 0,432 & 0,818 & 0,660 \\
\hline $\mathrm{X} 6$ & 0,731 & 0,873 & 0,741 \\
\hline $\mathrm{X} 7$ & 0,561 & 0,756 & 0,574 \\
\hline $\mathrm{YI}$ & 0,600 & 0,647 & 0,828 \\
\hline Y2 & 0,557 & 0,531 & 0,729 \\
\hline Y3 & 0,394 & 0,658 & 0,725 \\
\hline Y4 & 0,884 & 0,676 & 0,816 \\
\hline
\end{tabular}

Sumber: Data primer diolah, 2017

Berdasarkan hasil Tabel 4.5, setiap indikator berkorelasi lebih tinggi dengan konstruknya masing-masing dibandingkan dengan konstruk lainnya, sehingga dikatakan memiliki discriminant validity yang baik.

\section{Evaluasi Model Struktural (Inner Model)}

I. Evaluasi Goodness of Fit (GOF)

Untuk mengevaluasi GoF dalam penelitian ini, maka diperlukan nilai akhir $R^{2}$ dari tabel $R$ Square.

Tabel 4.7 Nilai $R$ Square

\begin{tabular}{|c|c|}
\hline & $R$ Square $\left(R^{2}\right)$ \\
\hline Kualitas Laporan Keuangan & 0,775 \\
\hline \multicolumn{2}{|c|}{ Sumber: Data primer diolah, 20I7 }
\end{tabular}

Nilai $R^{2}$ konstruk kualitas laporan keuangan adalah 0,775. Artinya, konstruk kualitas informasi dan pemahaman akuntansi secara simultan mampu menjelaskan variabilitas konstruk kualitas laporan keuangan sebesar $77,5 \%$.

Setelah dilakukan pengolahan data di atas, maka dapat melakukan validasi mode secara keseluruhan, yang dilihat dari goodness of fit (GoF) absolut yang formulanya adalah sebagai berikut.

$G o F=\sqrt{\overline{C o m \times R^{2}}}$

Com $=A V E$

GoF konstruk kualitas laporan keuangan adalah:

$G o F=\sqrt{0,667 \times 0,775}=0,719$
Nilai GoF terbentang antara 0 sd I dengan interpretasi nilai-nilai: 0, I (GoF kecil), 0,25 (GoF moderat), dan 0,36 (GoF besar). Nilai GoF yang didapat 0,719 dikatakan besar karena lebih dari 0,36. Maka dapat disimpulkan, secara keseluruhan model struktur adalah fit.

\section{Uji Hipotesis}

Untuk melihat signifikansi hubungan jalur antara konstruk, maka dilihat nilai t-hitung jalur seperti pada Gambar 4.3.

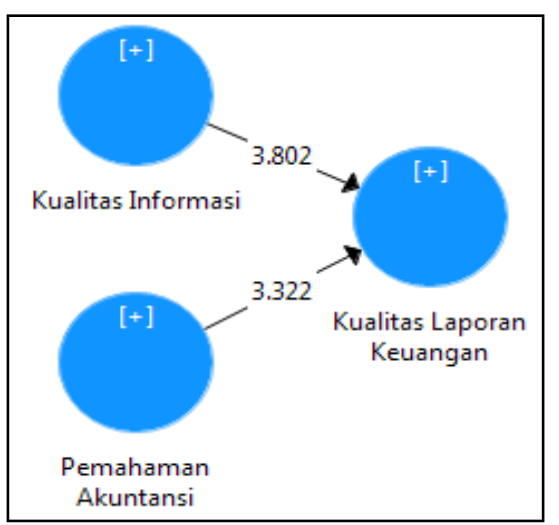

\section{Gambar 4.3 Nilai t-Hitung Hubungan Jalur} Sumber: SmartPLS 3.0

Berdasarkan Gambar 4.3 diketahui semua hubungan jalur bersifat signifikan, karena memiliki t-hitung lebih besar dari I,96; maka semua hipotesis diterima.

\section{Korelasi dan Persentase Pengaruh}

Langkah berikutnya yang dilakukan adalah melihat korelasi antara konstruk berdasarkan hasil Latent Variable Correlations berikut ini.

Tabel 4.6 Korelasi Antar Konstruk

\begin{tabular}{|l|c|c|c|}
\hline & $\begin{array}{c}\text { Kualitas } \\
\text { Informasi }\end{array}$ & $\begin{array}{c}\text { Pemahaman } \\
\text { Akuntansi }\end{array}$ & $\begin{array}{c}\text { Kualitas } \\
\text { Laporan } \\
\text { Keuangan }\end{array}$ \\
\hline $\begin{array}{l}\text { Kualitas } \\
\text { Informasi }\end{array}$ & $\mathrm{I}, 000$ & $\mathrm{I}, 000$ & \\
\hline $\begin{array}{l}\text { Pemahaman } \\
\text { Akuntansi }\end{array}$ & 0,816 & $0,8 \mathrm{I} \mathrm{I}$ & $\mathrm{I}, 000$ \\
\hline $\begin{array}{l}\text { Kualitas } \\
\text { Laporan } \\
\text { Keuangan }\end{array}$ & 0,709 & \\
\hline
\end{tabular}

Sumber: Data primer diolah, 2017

Adapun koefisien jalur dapat dilihat pada Gambar 4.4 berikut ini. 


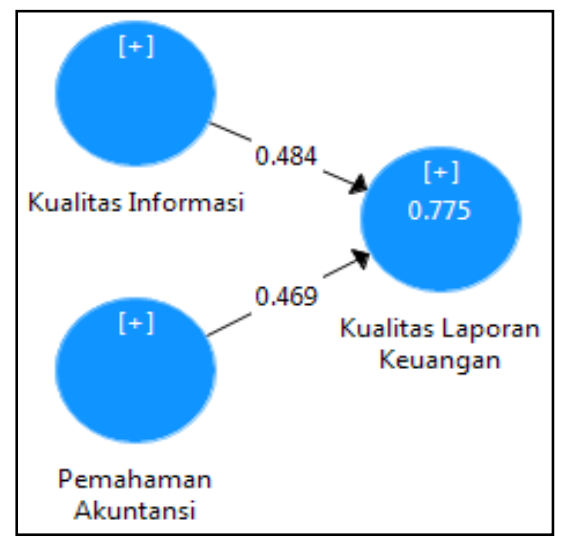

Gambar 4.4 Koefisien Jalur

Sumber: SmartPLS 3.0

Untuk mendapatkan persentase pengaruh antara konstruk adalah nilai korelasi antar konstruk dikali koefisien jalur dikali $100 \%$. Perhitungan persentase pengaruh antar konstruk sebagai berikut:

I. Persentase pengaruh kualitas informasi terhadap kualitas laporan keuangan adalah $0,709 \times 0,484 \times 100 \%=34,31 \%$

2. Persentase pengaruh pemahaman akuntansi terhadap kualitas laporan keuangan adalah $0,811 \times 0,469 \times 100 \%=38,03 \%$.

\section{PEMBAHASAN}

\section{a. Pengaruh Kualitas Informasi terhadap Kualitas Laporan Keuangan}

Kualitas informasi terhadap kualitas laporan keuangan diketahui memiliki nilai thitung lebih besar dari I,96 yaitu 3,802; maka $\mathrm{H}_{0}$ ditolak, artinya kualitas informasi mempunyai pengaruh signifikan terhadap kualitas laporan keuangan.

Berdasarkan hasil penelitian, kualitas informasi berpengaruh terhadap kualitas laporan dengan nilai korelasi sebesar 0,709 yang berarti kualitas informasi memberikan pengaruh cukup kuat berarah positif terhadap kualitas laporan keuangan.

Nilai persentase pengaruh kualitas informasi terhadap kualitas laporan keuangan sebesar 34,31\%; berarti kualitas informasi berkontribusi sebesar 34,31\% terhadap kualitas laporan keuangan.

Arah hubungan positif kualitas informasi terhadap kualitas laporan keuangan menunjukkann bahwa semakin baik kualitas informasi maka semakin baik kualitas laporan keuangan.

\section{b. Pengaruh Pemahaman Akuntansi terhadap Kualitas Laporan Keuangan}

Pemahaman akuntansi terhadap kualitas laporan keuangan diketahui memiliki nilai thitung lebih besar dari I,96 yaitu 3,322; maka $\mathrm{HI}$ diterima, artinya kualitas informasi mempunyai pengaruh signifikan terhadap kualitas laporan keuangan.

Berdasarkan hasil penelitian, Pemahaman akuntansi berpengaruh terhadap kualitas laporan dengan nilai korelasi sebesar 0,8Ilyang berarti pemahaman akuntansi memberikan pengaruh yang kuat berarah positif terhadap kualitas laporan keuangan.

Nilai persentase pengaruh pemahaman akuntansi terhadap kualitas laporan keuangan sebesar 38,03\%; berarti pemahaman akuntansi berkontribusi sebesar $38,03 \%$ terhadap kualitas laporan keuangan.

Arah hubungan positif pemahaman akuntansi terhadap kualitas laporan keuangan menunjukkann bahwa semakin baik pemahaman akuntansi maka semakin baik kualitas laporan keuangan.

\section{KESIMPULAN DAN SARAN}

\section{Kesimpulan}

Berdasar hasil penelitian dan pembahasan, maka dapat diambil kesimpulan sebagai berikut:

a. Kualitas informasi berpengaruh signifikan terhadap kualitas laporan keuangan pada usaha kecil dan menengah (UKM) di Kabupaten Tangerang.

b. Pengetahuan akuntansi berpengaruh signifikan terhadap kualitas laporan keuangan pada usaha kecil dan menengah (UKM) di Kabupaten Tangerang.

\section{Saran}

Berdasarkan kesimpulan yang telah dibahas sebelumnya, dapat dikemukakan beberapa saran yang diharapkan dapat bermanfaat. Adapun saran yang diberikan antara lain:

\section{a. Saran Operasional}

Untuk menghasilkan laporan keuangan usaha kecil dan menengah yang baik diperlukan kualitas informasi yang baik dan pengetahuan akuntansi yang baik pula.

b. Saran Akademis 
Dalam pengembangan ilmu akuntansi khususnya akuntansi sektor publik diharapkan hasil ini dapat dijadikan acuan agar kedepannya peneliti lain dapat menggunakan variabel yang sama, metode yang sama tetapi unit analisis, populasi dan sampel yang berbeda atau mencari variabel lain yang mempengaruhi kualitas laporan keuangan seperti komunikasi organisasi dan sistem informasi akuntansi pada usaha kecil dan menengah di daerah lainnya.

\section{IMPLIKASI MANAJERIAL}

Adapun implikasi manajerial dari penelitian ini adalah:

I. Pelatihan akuntansi berkaitan dengan kualitas informasi, dengan mengikuti pelatihan maka pemilik/manajer diharapkan dapat menambah pengetahuan akuntansinya dan dapat mengimplementasikan pada perusahaannya. Perusahaan yang sering mengikuti pelatihan akuntansi akan memiliki persepsi mengenai kualitas laporan keuangan yang lebih baik dibandingkan dengan perusahaan yang jarang atau bahkan tidak pernah mengikuti pelatihan akuntansi.

2. Teknologi informasi (TI) berkaitan dengan kualitas informasi. Teknologi informasi diperlukan sebagai alat bantu untuk menghasilkan kualitas informasi yang baik . Selain dapat menghemat waktu, perhitungannya pun akurat sehingga menghasilkan laporan keuangan yang berkualitas.

3. Integritas berkaitan dengan kualitas informasi. Integritas yang tinggi akan membuat perusahaan menyajikan laporan keuangan secara jujur, sesuai dengan nilai yang semestinya. Integritas yang tinggi diperlukan untuk menghasilkan laporan keuangan yang berkualitas.

4. Kontinyuitas berkaitan dengan pembandingan laporan keuangan, seperti yang tercantum pada SAK ETAP, salah satu syarat kualitatif laporan keuangan adalah dapat dibandingkan (IAI, 2009). Dengan melakukan pembukuan pada setiap periodenya, nilai-nilai yang tercantum pada laporan keuangan dapat dibandingkan dari satu periode ke periode lain.

5. Pengetahuan akuntansi berkaitan dengan pemahaman akuntansi. Pengetahuan akuntansi adalah faktor penting dalam pelaporan keuangan. Jika seorang pemilik/manajer memiliki pengetahuan akuntansi yang tinggi maka penggunaan informasi akuntansi akan semakin tinggi sehingga dapat meningkatkan kualitas laporan keuangan pada organisasinya.

6. Pengalaman dalam informasi akuntansi berkaitan dengan pemahaman akuntansi. Pengalaman dapat menambah tingkat pemahaman akuntansi, sehingga semakin berpengalaman seorang pemilik/manajer dalam informasi akuntansi maka pemanfaatan informasi akuntansi juga semakin tinggi dan laporan keuangan yang dihasilkan semakin berkualitas.

7. Pengetahuan pinjaman modal dapat mempengaruhi kualitas laporan keuangan. UKM yang memanfaatkan kredit bank dituntut untuk menghasilkan laporan keuangan yang berkualitas agar pihak bank percaya akan akuntabilitas dari perusahaan tersebut.

\section{DAFTAR PUSTAKA}

Arikunto, Suharmi. 2006, Prosedur Penelitian Suatu Pendekatan Praktik. Jakarta: Rineka Cipta.

G. David Garson. 2014, Partial Least Squares: Regresion \& Structural Equation Models. NC: Statistical Publishing Associates.

Gelinas, Jr., Ulric J., Dull, Richard B. 2010, Accounting Information Systems. 8th edition. South Western Cengage Learning.

James, A. Hall. 2007, Sistem Informasi Akuntansi. Edisi Ketiga. Terjemahan Amir Abadi Yusuf. Jakarta: Salemba Empat.

Sekaran, Uma dan Roger Bougie. 2009, Research Methods for Business: A Skill Building Approach. 5th ed. United Kingdom: John Wiley and Sons.

Sugiyono. 2012, Metode Penelitian

Kuantitatif Kualitatif dan $R$ \& $D$. Bandung: Alfabeta.

Supomo, Bambang dan Nur Indriantoro. 2002, Metodologi Penelitian Bisnis, Cetakan Kedua. Yogyakara: Penerbit BFEE UGM.

Warsono, Sony. 2010, Akuntansi UMKM Ternyata Mudah Dipahami dan Dipraktikan. Yogyakarta: Asgard Chapter. 
Yamin, Sofyan. 2009, Structural Equation

Modeling. Jakarta: Salemba Infotek.

Yuliani, Syafrida. 2010, Pengaruh

Pemahaman Akuntansi,

Pemanfaatan Sistem Informasi

Akuntansi Keuangan Daerah Dan

Peran Internal Audit Terhadap

Kualitas Laporan Keungan

Pemerintah Daerah (Studi Empiris

Pada Pemerintah Kota Banda

Aceh). Jurnal Telaah dan Riset Akuntansi

Vol 3 No 2 hal 206-220. 